\title{
Quality of life of women
}

\section{with postmenopausal pelvic organ prolapse}

Jakość życia kobiet z zaburzeniami statyki narządu rodnego w wieku pomenopauzalnym

\author{
Julia Nawrot ${ }^{1}$, Magdalena Humaj-Grysztar², Agnieszka Gniadek³, \\ Dorota Matuszyk ${ }^{4}$, Renata Biernat ${ }^{5}$
}

\begin{abstract}
'Doctoral student, Faculty of Health Sciences, Jagiellonian University Medical College/ Studentka studiów III stopnia, Wydział Nauk o Zdrowiu, Uniwersytet Jagielloński Collegium Medicum w Krakowie ${ }^{2}$ Department of Nursing and Obstetrics, Faculty of Health Sciences, Jagiellonian University Medical College/ Zakład Opieki Ginekologicznej, Wydział Nauk o Zdrowiu, Uniwersytet Jagielloński Collegium Medicum w Krakowie ${ }^{3}$ Department of Nursing and Obstetrics, Faculty of Health Sciences, Jagiellonian University Medical College/ Zakład Zarządzania Pielęgniarstwem i Pielęgniarstwa Epidemiologicznego, Wydział Nauk o Zdrowiu Uniwersytet Jagielloński Collegium Medicum w Krakowie ${ }^{4}$ Department of Nursing and Obstetrics, Faculty of Health Sciences, Jagiellonian University Medical College/ Pracownia Podstaw Opieki Położniczej, Wydział Nauk o Zdrowiu Uniwersytet Jagielloński Collegium Medicum w Krakowie

${ }^{5}$ Midwifery graduate, Faculty of Health Sciences, Jagiellonian University Medical College/ Absolwentka kierunku Położnictwo, Wydział Nauk o Zdrowiu, Uniwersytet Jagielloński Collegium Medicum w Krakowie
\end{abstract}

CORRESPONDING AUTHOR/AUTOR DO KORESPONDENCJ:

Julia Nawrot

Wydział Nauk o Zdrowiu

Uniwersytet Jagielloński Collegium Medicum

ul. Kopernika 25, 31-501 Kraków e-mail: julia.nawrot@doctoral.uj.edu.pl

\section{STRESZCZENIE JAKOŚCZ ŻCIA KOBIETZZABURZENIAMI STATYKI NARZADU RODNEGO W WIEKU POMENOPAUZALNYM}

Cel pracy. Celem pracy była ocena jakości życia kobiet z zaburzeniami statyki narządu rodnego w okresie pomenopauzalnym.

Materiał i metodyka. Badaniami objęto 45 pacjentek Oddziału Ginekologii i Onkologii Szpitala Uniwersyteckiego w Krakowie. Badania przeprowadzono z zastosowaniem metody sondażu diagnostycznego, techniki ankiety oraz narzędzi: autorskiego kwestionariusza ankiety oraz kwestionariusza do oceny jakości życia Short Form of Health Status Questionare (SF-36v2). Uzyskane wyniki badań poddano analizie statystycznej.

Wyniki. Uzyskane wyniki wykazały, iż respondentki oceniały swoją jakość życia jako niższą od normy założonej przez autorów kwestionariusza SF-36v2. Wykazano istotną statystycznie $(p<0,05)$ zależność pomiędzy wiekiem badanych a obniżeniem jakości życia. Wnioski. Jakość życia badanych kobiet z zaburzeniami statyki narządu rodnego była niska. Wiek miał wpływ na obniżenie subiektywnej oceny jakości życia, a najczęstszym objawem związanym z zaburzeniami statyki narządu rodnego było odczuwanie parcia na mocz.

Słowa kluczowe: zaburzenia statyki narządu rodnego, menopauza, jakość życia

\section{ABSTRACT}

\section{QUALIV OF LIFE OF WOMEN WITH POSTMENOPAUSAL PELIIC ORGAN PROLAPSE}

Aim. The aim of the study was to evaluate the quality of life of women with pelvic organ prolapse during the postmenopausal period. Material and methodology. The study group consisted of 45 patients of the Department of Gynecology and Oncology at the University Hospital in Cracow The study was conducted as a diagnostic survey using the following survey techniques: author's questionnaire and the Short Form of Health Status Questionnaire (SF-36v2).

Results. The results showed that the respondents rated their quality of life as lower than the norm set by the authors of the SF-36V2 questionnaire. A statistically significant $(p<0.05)$ correlation between the age of the subjects and the quality of life was found.

Conclusions. The quality of life of the women with the pelvic organ prolapse was low. The reason of the subjective assessment of quality of life was age. The most common symptom associated with pelvic organ prolapse was feeling the urge to urinate.

Key words: pelvic organ prolapse, menopause, quality of life

\section{INTRODUCTION}

Perimenopausal period is the time of changes for women both in the biological, mental and social functioning. One of the most onerous symptoms that may occur during this time are those associated with disorders of pelvic organ prolapseprolapsed, which is defined as a descending or drooping of female genital organs beyond their normal anatomical confines [1].To diagnose the stage of pelvic organ prolapsed, a Pelvic Organ Prolapse Quantification (POPQ) is used. The advantages of this scale are its high specificity and the objective way of the evaluation. In this scale four stages of pelvic organ prolapse are distinguished $[2,3,4]$. Common causes of this disorder are loss 
of support to one (or both) vaginal walls, the deformation of the structure divided by the change in force that caused the deformation [5]. All of the changes which take place in the female body during perimenopause may lead to multiple symptoms negatively affecting the quality of life.

\section{AIM}

The aim of this study was to evaluate the quality of life of women with pelvic organ prolapse disorders in postmenopausal period. Moreover the aim was to examine whether there is any relationship between age, Body Mass Index (BMI), weight of workloads, the number of births, the frequency of gynecologists visit and subjective assessment of quality of life. An attempt to identify the most common, among respondents, symptoms associated with disorders of pelvic organ prolapse was made as well.

\section{MATERIAL AND METHODS}

The study was conducted between November 2015 and March 2016 among 45 patients of the Department of Gynecology and Oncology at the University Hospital in Cracow. The inclusion criteria were the following: postmenopausal stadium and stage 3 or 4 in POP-Q scale. The study met the requirements of the Helsinki Declaration. The participation was voluntary and the respondents were informed about its anonymity and the possibility of resignation at any stage of the study.

An author's diagnostic questionnaire and a questionnaire to assess quality of life (Short Form Health Status of Questionnaire SF-36v2) was used. The permission to use SF-36v2 was granted by Optum (license no QM031978). The results were analyzed with Microsoft Excel 2013 and Statistica v. 12. The relationship between the variables studied and the areas of quality of life was measured using Spearman's rank correlation. Statistical significance was assumed at $\alpha=0.05$. The analysis of data from the SF-36v2 was made using the key: Health Outcomes Scoring Software 4.5.

\section{RESULTS}

The study group were women with a mean age of 67 years. Analysis of BMI showed that the largest group of $66.7 \%$ of women were overweight $(n=30)$. Obesity was reported in $20 \%$ of women $(n=9)$. Normal weight was observed only in $13.3 \%$ of patients $(n=6)$. In $31 \%$ of the respondents $(n=14)$ the spine defects were reported. Chronic constipation was found in $22 \%$ of patients $(\mathrm{n}=10)$, pelvic floor defects in $9 \%(\mathrm{n}=4)$ and persistent cough in $6.6 \%(n=3)$. More than $22 \%(n=10)$ of patients from the study group previously underwent the pelvic surgery due to various reasons. As many as $60 \%(n=27)$ of respondents declared physical work. Family history of the pelvic organ prolapse was confirmed in $16 \%(n=7)$ of patients.

While analyzing the risk factors for obstetric disorders related to the obstetric past, almost $90 \%$ of the woman
( $\mathrm{n}=40$ ) had at least one child. Most of them were twice or three times pregnant (33.3\% and $20 \%$, respectively). When it comes to $78.8 \%$ of women $(n=35)$, they went through one or more vaginal deliveries, while $22.2 \%$ had one or more caesarean section: one cesarean section $80 \%(n=8)$, two cesarean sections $-20 \%(n=2)$. The frequency of instrumental delivery in the study group was $15 \%(n=7)$. Three patients $(7 \%)$ declared the use of forceps and two $(4 \%)$ the use of vacuum. Both manual removal of the placenta or Kristeller maneuver was indicated by one person. Eleven women in the study group (27.5\%) declared that the birth weight of newborns was over $4001 \mathrm{~g}$. The most common finding according to the declared symptoms associated with pelvic organ prolapse was urgency $(73 \%, \mathrm{n}=33)$, urinary incontinence $(67 \%$, $\mathrm{n}=30)$, increased urination $(67 \% \mathrm{n}=30)$ and the extending of the genital tract from the vagina $(67 \%, \mathrm{n}=30)$. Table 1. shows the frequency of pelvic floor prolapse symptoms in the study group.

Tab. 1. Frequency of pelvic organ prolapse symptoms (more than one answer was possible)

\begin{tabular}{|l|c|c|c|c|}
\hline \multirow{2}{*}{\multicolumn{1}{|c|}{ Symptom }} & \multicolumn{2}{c|}{$\begin{array}{c}\text { Women who } \\
\text { declared }\end{array}$} & $\begin{array}{c}\text { Women who didn't } \\
\text { declare }\end{array}$ \\
\cline { 2 - 5 } & $\mathrm{N}$ & $\%$ & $\mathrm{~N}$ & $\%$ \\
\hline Fullness in the crotch & 27 & $60 \%$ & 18 & $40 \%$ \\
\hline Pressure & 20 & $44.4 \%$ & 25 & $55.6 \%$ \\
\hline Heaviness & 12 & $26.7 \%$ & 33 & $73.3 \%$ \\
\hline Extension of the genital tract & 30 & $66.7 \%$ & 15 & $33.3 \%$ \\
\hline Gas incontinence & 4 & $8.9 \%$ & 41 & $91.1 \%$ \\
\hline Faecal incontinence & 1 & $2.2 \%$ & 44 & $97.8 \%$ \\
\hline Incomplete defecation & 5 & $11.1 \%$ & 40 & $88.9 \%$ \\
\hline $\begin{array}{l}\text { Necessity of strong pressure during } \\
\text { defecation }\end{array}$ & 22 & $48.9 \%$ & 23 & $51.1 \%$ \\
\hline $\begin{array}{l}\text { Necessity of lifting of extending genital } \\
\text { tract to stop urination }\end{array}$ & 4 & $8.9 \%$ & 41 & $91.1 \%$ \\
\hline Urinary incontinence & 30 & $66.7 \%$ & 15 & $33.3 \%$ \\
\hline Increased urination & 30 & $66.7 \%$ & 15 & $33.3 \%$ \\
\hline Urgency & 33 & $73.3 \%$ & 12 & $26.7 \%$ \\
\hline Incomplete urination & 28 & $62.2 \%$ & 17 & $37.8 \%$ \\
\hline $\begin{array}{l}\text { Necessity of palpation of extended } \\
\text { genital tract to facilitate urination }\end{array}$ & 8 & $17.8 \%$ & 37 & $82.2 \%$ \\
\hline $\begin{array}{l}\text { Change of body position to initiate } \\
\text { or stop urination }\end{array}$ & 5 & $11.1 \%$ & 40 & $88.9 \%$ \\
\hline Abnormal urine stream & & & 36 & $80 \%$ \\
\hline
\end{tabular}

The results of the subjective quality of life measurement of the SF-36v2 scale showed that the mean value of all tested agents measured on a scale of physical (PCS, Physical Component Summary) and mental (MCS, Mental Component Summary) scores (i.e. efficiency of the physical activity limitations due to the lack of physical, bodily pain, general health perception, vitality, social functions, activity limitations due to emotional problems in bed emotional health), were granted below the norm of 50 points as recommended in SF-36v2. This indicates lower quality of life than the questionnaire set up by the authors' standards (Table 2.). 
Tab. 2. The statistical measurements of the SF-36v2 scale

\begin{tabular}{|l|c|c|}
\hline Quality of life indicator & $X \pm S D$ & ME (min-max) \\
\hline PF & $45.46 \pm 8.76$ & $47.97(26.92-57.54)$ \\
\hline RP & $45.13 \pm 8.06$ & $45.93(30.21-57.16)$ \\
\hline BP & $46.01 \pm 9.82$ & $46.68(30.55-62.00)$ \\
\hline GH & $45.89 \pm 12.48$ & $47.48(21.33-66.50)$ \\
\hline VT & $45.80 \pm 7.01$ & $46.66(31.80-61.51)$ \\
\hline SF & $42.75 \pm 9.49$ & $42.30(27.26-57.34)$ \\
\hline RE & $47.74 \pm 8.83$ & $52.69(24.83-56.17)$ \\
\hline MH & $44.12 \pm 6.25$ & $43.02(29.94-56.10)$ \\
\hline PCS & $45.73 \pm 9.48$ & $48.28(28.37-60.93)$ \\
\hline MCS & $45.32 \pm 6.18$ & $44.96(31.48-55.51)$ \\
\hline
\end{tabular}

$\mathrm{X}$ - arithmetic mean, SD - standard deviation, ME - median, min-minimum, max-maximum; PF - Physical Function RP - Role Physical, BP - Bodily Pain, GH - General Health, VT - Vitality; SF - Social Function, RE - Role Emotional, MH - Mental Health, PCS - Physical Component Summary; MCS - Mental Component Summary

In the study, the group limitations in terms of selfcare and physical activity (PCS indicator) (Table 2.) were found. The average values of MCS prove the frequent stress occurrence and mental limitations in social functioning. General health perception in the group was low and it may deteriorate (indicator $\mathrm{GH}, \mathrm{x}=45.9$ ). The average value of PF (Physical Function) and RP (Role Physical) below accepted point means that the study group was limited in physical exercises, work and activities of daily living. The VT indicator (Vitality) below the accepted standard indicates that woman were accompanied with fatigue and a sense of exhaustion. On the basis of the obtained results, it can be stated that the emotional problems can impact on the social functioning of women (SF indicator, Social Function). The linking between emotional problems with work and other daily activities (RE indicator, Role Emotional) was also observed. The average value of $\mathrm{MH}$ (Mental Health indicator) in the study group may suggest anxiety and depressive mood.

The relationship between the quality of life measured in SF-36v2 and the variables that may affect the subjective perception of one's own health, were checked for further analysis. Statistically significant correlation between age of patients and the PF, RP BP, PCS indicators was found. The correlation is negative and the strength of the correlation is weak or moderate (Table 3.).

Tab. 3. The correlation between the indicators of quality of life and age

\begin{tabular}{|l|c|c|c|}
\hline Quality of life indicator & $\mathrm{N}$ & $\mathrm{R}$ & $\mathrm{p}$ \\
\hline PF & 45 & $\mathbf{- 0 . 4 4}$ & $\mathbf{0 . 0 0 2 3}$ \\
\hline RP & 45 & $\mathbf{- 0 . 5 2}$ & $\mathbf{0 . 0 0 0 2}$ \\
\hline BP & 45 & $\mathbf{- 0 . 3 1}$ & $\mathbf{0 . 0 3 9 3}$ \\
\hline GH & 45 & -0.16 & 0.2898 \\
\hline VT & 45 & -0.14 & 0.3598 \\
\hline SF & 45 & $-\mathbf{0 . 4 4}$ & $\mathbf{0 . 0 0 2 3}$ \\
\hline RE & 45 & $-\mathbf{0 . 3 5}$ & $\mathbf{0 . 0 1 7 3}$ \\
\hline MH & 45 & -0.21 & 0.1576 \\
\hline PCS & 45 & $-\mathbf{0 . 3 7}$ & $\mathbf{0 . 0 1 1 8}$ \\
\hline MCS & 45 & -0.25 & 0.1017 \\
\hline
\end{tabular}

Spearman's correlation analysis, $\mathrm{p}=0.05$
The analysis of the relationship between the quality of life indicators from SF-36v2 and age, BMI variables, heavy lifting during work, parity including vaginal and via caesarean section deliveries, and the frequency of visits with their gynecologists did not show statistically significant correlation.

\section{DISCUSSION}

Of all the examined women, $90 \%$ gave birth, out of which, $78.8 \%$ had at least one vaginal birth. This disproportion between the number of patients who had a vaginal childbirth and those who had caesarean section is consistent with the conclusions drawn from the systematic review carried out by Norwegian researchers Rørtveit and Hannestad. They revealed that women who had a vaginal birth have more often a decent of reproductive organs and incontinence compared to those who had cesarean sections [6]. Overweight and obesity are risk factors that increase the risk of pelvic organ prolapse [7]. Study findings seems to confirm this fact, because $66.7 \%$ of the respondents were overweight, and $20 \%$ of them were obese.

In Rodríguez-Mias et al. research conducted on a group of 1042 women, an attempt was made to identify the factors affecting the occurrence of pelvic organ prolapse and urinary incontinence. It has been shown that women with pelvic organ prolapse disorders often have surgical births in their medical history and often give birth to children with increased body weight [8]. In our own study, 15\% of the respondents had delivery and $27.5 \%$ had a baby weighing more than 4001 grams.

One of the most frequent symptoms associated with pelvic organ prolapse were urgency (73\%) and urinary incontinence $(66.7 \%)$. These disorders can significantly reduce the quality of life of women, as confirmed in Popłocka-Molinska et al. study [9]. They found that incontinence reduces the quality of life of respondents in the area of family (72\%), professional (49\%) and social (40\%) life.

In the study group, the quality of life was lower in each of the areas included in the SF-36v2 questionnaire. Similar results were obtained in Chan et al. study among 308 women with pelvic organ prolapse. An assessment of their quality of life using the SF-36v2 questionnaire was made [10]. The quality of life was lower than the questionnaire norm like in the presented study.

\section{CONCLUSIONS}

1. Mean quality of life of the respondents was lower than the SF-36v2 authors' norm in all areas.

2. The age of women significantly influenced the decrease in subjective assessment of quality of life in areas such as physical activity according to lack of physical health, bodily pain, social function and activity limitations due to emotional problems and the physical component summary. 
3. There was no statistically significant relationship between BMI, weight of workloads, number of births, frequency of gynecologist appointments and subjective assessment of the quality of life.
4. The most common symptoms associated with renal pelvic organ prolapse was the urge to urinate, observation of the extension of the genital tract from the vagina, urinary incontinence, and increased frequency of urination.

\section{Jakość życia kobiet z zaburzeniami statyki narządu rodnego $\mathrm{w}$ wieku pomenopauzalnym}

\section{WPROWADZENIE}

Okres okołomenopauzalny jest czasem zmian dla kobiety zarówno w funkcjonowaniu biologicznym, psychicznym jak i społecznym. Jednymi z najbardziej uciążliwych dolegliwości mogących pojawić się w tym czasie są te związane z zaburzeniami statyki narządu rodnego. Definiuje się je jako obniżenie narządów miednicy poniżej ich normalnego usytuowania [1]. Do oceny obniżenia narządu rodnego stosowana jest skala POPQ (Pelvic Organ Prolapse Quantification, Skala oceny obniżenia narządu rodnego). Zaletami tej skali jest wysoka specyficzność i obiektywny sposób oceny obniżenia narządu rodnego. W skali tej wyróżniamy 4 stopnie zaawansowania wypadania narządu rodnego $[2,3,4]$. Jako główne przyczyny występowania tych zaburzeń wymienia się niewydolność dna miednicy, osłabienie aparatu zawieszającego i podporowego, istnienie odchyleń pomiędzy siłami oddziałującymi na narząd rodny a siłami utrzymującymi jego prawidłowe położenie oraz zaburzenia ciśnienia śródbrzusznego [5]. Wszystkie zmiany zachodzące w organizmie kobiety w okresie okołomenopauzalnym mogą prowadzić do wystąpienia wielu objawów negatywnie wpływających na ich jakość życia.

\section{CEL PRACY}

Celem niniejszej pracy była ocena jakości życia kobiet z zaburzeniami statyki narządu rodnego w okresie pomenopauzalnym oraz zbadanie czy istnieje zależność pomiędzy wiekiem, wskaźnikiem masy ciała (Body Mass Index, $\mathrm{BMI})$, masą ciężarów podnoszonych w trakcie pracy, liczbą porodów oraz częstotliwością wizyt u ginekologa, a subiektywną oceną jakości życia. Podjęta została również próba identyfikacji najczęściej występujących wśród respondentek objawów związanych z zaburzeniami statyki narządu rodnego.

\section{MATERIAŁ I METODY}

Badanie przeprowadzone zostało od listopada 2015 do marca 2016 roku wśród 45 pacjentek Oddziału Klinicznego Ginekologii i Onkologii Szpitala Uniwersyteckiego w Krakowie Za kryterium włączenia do badania przyjęto stan po menopauzie oraz diagnozę lekarską wskazującą na III i IV stopień wypadania według POPQ. Badanie spełniało wymogi Deklaracji Helsińskiej, udział w nim był dobrowolny, a respondentki zostały poinformowane o jego anonimowości oraz o możliwości rezygnacji na każdym etapie jego trwania.
Metodą wybraną do przeprowadzenia badania był sondaż diagnostyczny $\mathrm{z}$ wykorzystaniem autorskiego kwestionariusza ankiety oraz kwestionariusza oceny jakości życia SF-36v2 (Short Form of Health Status Questionare) na użycie którego uzyskano zgodę wydaną przez firmę Optum (licencja nr QM031978).

Uzyskane wyniki poddane zostały analizie statystycznej przy użyciu arkusza kalkulacyjnego Microsoft Excel 2013 oraz programu Statistica v. 12. Związek między badanymi zmiennymi a obszarami jakości życia badano przy użyciu korelacji porządku rang Spearmana. Na potrzeby badania przyjęto istotność statystyczną $\alpha=0,05$. Analizy danych z kwestionariusza SF-36v2 dokonano z zastosowaniem klucza: Health Outcomes Scoring Software 4.5.

\section{WYNIKI BADAŃ}

Badaną grupę stanowiły kobiety, których średnia wieku wynosiła około 67 lat. Analiza BMI wykazała, że najliczniejszą grupę, bo aż 66,7\% respondentek stanowiły kobiety $\mathrm{z}$ nadwagą $(\mathrm{n}=30)$. Otyłość stwierdzono u $20 \%$ badanych $(n=9)$, a prawidłową masę ciała zaledwie u $13,3 \%$ $(n=6)$ kobiet. W oparciu o wywiad chorobowy i czynniki sprzyjające występowaniu zaburzeń statyki narządu rodnego zaobserwowano, że najwięcej, bo $31 \%$ respondentek $(n=14)$ zgłosiło występowanie wad kręgosłupa. 22\% pacjentek $(n=10)$ zadeklarowało występowanie przewlekłych zaparć, 9\% (n=4) występowanie wad w obrębie miednicy kostnej, a 6,6\% $(n=3)$ choroby z towarzyszącym uporczywym kaszlem. Na podstawie pytań o przeszłość ginekologiczną stwierdzono, że 22\% (n=10) kobiet z badanej grupy miało przeprowadzany w przeszłości zabieg chirurgiczny w obrębie miednicy. Wykonywanie w przeszłości lub obecnie pracy wymagającej wysiłku fizycznego zadeklarowała 60\% $(n=27)$ respondentek. Dodatni wywiad rodzinny w odniesieniu do zaburzeń statyki narządu rodnego potwierdzono u $16 \%(n=7)$ badanych.

Analizując czynniki ryzyka występowania zaburzeń statyki narządu rodnego związanych z przeszłością położniczą wykazano, że niemal $90 \%$ badanych $(\mathrm{n}=40)$ urodziło przynajmniej jedno dziecko. Większość pacjentek była dwu lub trzykrotnie w ciąży (odpowiednio 33,3\% i $20 \%)$. W badanej grupie $78,8 \%$ kobiet $(n=35)$ przebyło jeden lub więcej porodów drogami natury, natomiast $22,2 \%$ jedno lub więcej cięć cesarskich, w tym $80 \%(n=8)$ jedno cięcie, a 20\% ( $n=2)$ dwa zabiegi cięcia cesarskiego. Częstotliwość występowania porodów zabiego- 
wych $\mathrm{w}$ trakcie porodu drogami natury $\mathrm{w}$ badanej grupie wyniosła $15 \%(\mathrm{n}=7)$. W całej populacji objętych badaniem trzy pacjentki (7\%) potwierdziły ukończenie porodu przy pomocy kleszczy położniczych, zaś u dwóch (4\%) wykorzystano w czasie porodu próżniociąg położniczy. Wykonanie ręcznego wydobycia łożyska wskazała 1 osoba, zastosowanie manewru Kristellera również 1 osoba. Z badanej grupy, 11 kobiet $(27,5 \%)$ zadeklarowało, że masa urodzeniowa noworodków wyniosła powyżej $4001 \mathrm{~g}$.

Badając częstość występowania dolegliwości związanych z zaburzeniami statyki narządu rodnego wykazano, że do najczęściej zgłaszanych należą: parcie na mocz (73\%, $\mathrm{n}=33)$, nietrzymanie moczu $(67 \%, \mathrm{n}=30)$, zwiększona częstość oddawania moczu $(67 \%, \mathrm{n}=30)$ oraz obserwacja narządu rodnego wysuwającego się z pochwy $(67 \%$, $\mathrm{n}=30$ ). W Tabeli 1 przedstawiono częstość występowania objawów obniżenia narządu rodnego w badanej grupie.

Tab. 1. Częstość występowanie objawów obniżenia narządu rodnego (możliwe było udzielenie więcej niż 1 odpowiedzi)

\begin{tabular}{|c|c|c|c|c|}
\hline \multirow[t]{2}{*}{ Objaw } & \multicolumn{2}{|c|}{\begin{tabular}{|c|}
$\begin{array}{c}\text { Kobiety, u których } \\
\text { występuje }\end{array}$ \\
\end{tabular}} & \multicolumn{2}{|c|}{$\begin{array}{l}\text { Kobiety, u których } \\
\text { nie występuje }\end{array}$} \\
\hline & $\mathrm{N}$ & $\%$ & N & $\%$ \\
\hline Uczucie pełności w kroczu & 27 & $60 \%$ & 18 & $40 \%$ \\
\hline Uczucie parcia & 20 & $44,4 \%$ & 25 & $55,6 \%$ \\
\hline Uczucie ciężkości & 12 & $26,7 \%$ & 33 & $73,3 \%$ \\
\hline $\begin{array}{l}\text { Obserwacja narządu rodnego } \\
\text { wysuwającego się z pochwy }\end{array}$ & 30 & $66,7 \%$ & 15 & $33,3 \%$ \\
\hline Nietrzymanie gazów & 4 & $8,9 \%$ & 41 & $91,1 \%$ \\
\hline Nietrzymanie stolca & 1 & $2,2 \%$ & 44 & $97,8 \%$ \\
\hline Uczucie niekompletnego wypróżnienia & 5 & $11,1 \%$ & 40 & $88,9 \%$ \\
\hline $\begin{array}{l}\text { Konieczność silnego parcia podczas } \\
\text { oddawania stolca }\end{array}$ & 22 & $48,9 \%$ & 23 & $51,1 \%$ \\
\hline $\begin{array}{l}\text { Konieczność palpacyjnego } \\
\text { odprowadzenia wypadającego } \\
\text { narządu rodnego w celu zakończenia } \\
\text { wypróżnienia }\end{array}$ & 4 & $8,9 \%$ & 41 & $91,1 \%$ \\
\hline Nietrzymanie moczu & 30 & $66,7 \%$ & 15 & $33,3 \%$ \\
\hline Zwiększona częstość oddawania moczu & 30 & $66,7 \%$ & 15 & $33,3 \%$ \\
\hline Parcie na mocz & 33 & $73,3 \%$ & 12 & $26,7 \%$ \\
\hline $\begin{array}{l}\text { Uczucie niekompletnego opróżnienia } \\
\text { pęcherza }\end{array}$ & 28 & $62,2 \%$ & 17 & $37,8 \%$ \\
\hline $\begin{array}{l}\text { Konieczność palpacyjnego odprowadza- } \\
\text { nia wypadającego narządu rodnego } \\
\text { w celu ułatwienia oddawania moczu }\end{array}$ & 8 & $17,8 \%$ & 37 & $82,2 \%$ \\
\hline $\begin{array}{l}\text { Zmiana pozycji ciała w celu } \\
\text { zapoczątkowania lub zakończenia } \\
\text { oddawania moczu }\end{array}$ & 9 & $20 \%$ & 36 & $80 \%$ \\
\hline Nieprawidłowy strumień moczu & 5 & $11,1 \%$ & 40 & $88,9 \%$ \\
\hline
\end{tabular}

W analizie wyników pomiaru subiektywnej oceny jakości życia według kwestionariusza SF-36v2 wykazano, że średnie wartości wszystkich badanych czynników mierzonych na skali fizycznej (Physical Component Summary, PCS) oraz psychicznej (Mental Component Summary, MCS), tj. sprawność fizyczna, ograniczenie aktywności z powodu braku zdrowia fizycznego, odczuwanie bólu, ogólna percepcja zdrowia, witalność, funkcje socjalne, ograniczenie aktywności z powodu problemów emocjonalnych, zdrowie emocjonalne, uzyskały wartości poniżej przyjętej normy 50 punktów (zgodnej z zaleceniem autorów narzędzia SF-36v2). Wskazuje to na jakość życia niższą od normy założonej przez autorów kwestionariusza (Tabela 2).

Tab. 2. Charakterystyka statystyczna pomiarów SF-36v2

\begin{tabular}{|l|c|c|}
\hline Wskaźnik jakości życia & $X \pm$ SD & ME (min-max) \\
\hline PF & $45,46 \pm 8,76$ & $47,97(26,92-57,54)$ \\
\hline RP & $45,13 \pm 8,06$ & $45,93(30,21-57,16)$ \\
\hline BP & $46,01 \pm 9,82$ & $46,68(30,55-62,00)$ \\
\hline GH & $45,89 \pm 12,48$ & $47,48(21,33-66,50)$ \\
\hline VT & $45,80 \pm 7,01$ & $46,66(31,80-61,51)$ \\
\hline SF & $42,75 \pm 9,49$ & $42,30(27,26-57,34)$ \\
\hline RE & $47,74 \pm 8,83$ & $52,69(24,83-56,17)$ \\
\hline MH & $44,12 \pm 6,25$ & $43,02(29,94-56,10)$ \\
\hline PCS & $45,73 \pm 9,48$ & $48,28(28,37-60,93)$ \\
\hline MCS & $45,32 \pm 6,18$ & $44,96(31,48-55,51)$ \\
\hline
\end{tabular}

$X$ - średnia arytmetyczna, SD - odchylenie standardowe, ME - Mediana, min-minimum, max-maksimum PF - Physical Function (sprawność fizyczna); RP - Role Physical (ograniczenie aktywności z powodu braku zdrowia fizycznego; BP - Bodily Pain (odczuwanie bólu); GH - General Health (ogólna percepcja zdrowia); VT - Vitality (witalność); SF-Social Function (funkcja socjalna); RE - Role Emotional (ograniczenie aktywności z powodu problemów emocjonalnych); $M H$ - Mental Health (zdrowie emocjonalne); $P(S-$ Physical Component Summary (podsumowanie komponentów fizycznych); MCS - Mental Component Summary (podsumowanie komponentów psychicznych)

Prezentowane wyniki wskazują, że w badanej grupie występują ograniczenia w zakresie samoopieki oraz aktywności fizycznej (wskaźnik PCS) (Tabela 2). Jednocześnie średnie wartości wskaźnika MCS świadczą o częstym występowaniu stresu, a także ograniczeń natury psychicznej w funkcjonowaniu społecznym oraz wypełnianiu ról społecznych. Ogólna percepcja zdrowia w badanej grupie jest niska, przy jednoczesnym przeświadczeniu, że stan ten może ulec pogorszeniu (wskaźnik General Health GH, $\mathrm{x}=45,9)$. Średnia wartość wskaźnika sprawności fizycznej (Physical Function PF) oraz wskaźnika ograniczenia aktywności z powodu braku zdrowia fizycznego (Role Physical, RP) poniżej przyjętej normy oznacza, że w badanej grupie obserwuje się ograniczenia w aktywności fizycznej oraz w pracy i wykonywaniu codziennych czynności. Wskaźnik witalności (Vitality, VT) poniżej przyjętej normy wskazuje na to, że badanym towarzyszy zmęczenie i poczucie wyczerpania. Na podstawie uzyskanych wyników wskaźnika funkcji socjalnych (Social Function, SF) można stwierdzić, że wpływ na funkcjonowanie społeczne kobiet mogą mieć problemy natury emocjonalnej. Zaobserwowano również istnienie związku problemów emocjonalnych $\mathrm{z}$ trudnościami w pracy i innymi codziennymi czynnościami (wskaźnik Role Emotional, RE). Średnia wartość wskaźnika zdrowia emocjonalnego (Mental Health, MH) oznacza natomiast, że w badanej grupie występuje czasem zdenerwowanie i depresyjny nastrój.

W dalszej analizie zbadano związek pomiędzy wskaźnikami jakości życia SF-36v2, a zmiennymi mogącymi mieć wpływ na subiektywne postrzeganie własnego zdrowia przez kobiety. Wykazano istotną statystycznie zależność między wiekiem badanych, a wskaźnikami PF, RP BP, PCS. W badanej grupie wyniki wskazują na ujemną korelację pomiędzy wyżej wymienionymi zmiennymi, a wiekiem, a także słabą lub umiarkowaną siłę analizowanych związków (Tabela 3). 
Tab. 3. Korelacja między wskaźnikami jakości życia, a wiekiem

\begin{tabular}{|l|c|c|c|}
\hline Wskaźnik jakości życia & $\mathrm{N}$ & $\mathrm{R}$ & $\mathrm{p}$ \\
\hline PF & 45 & $-\mathbf{0 , 4 4}$ & $\mathbf{0 , 0 0 2 3}$ \\
\hline RP & 45 & $-\mathbf{0 , 5 2}$ & $\mathbf{0 , 0 0 0 2}$ \\
\hline BP & 45 & $-\mathbf{0 , 3 1}$ & $\mathbf{0 , 0 3 9 3}$ \\
\hline GH & 45 & $-0,16$ & 0,2898 \\
\hline VT & 45 & $-0,14$ & 0,3598 \\
\hline SF & 45 & $-\mathbf{0 , 4 4}$ & $\mathbf{0 , 0 0 2 3}$ \\
\hline RE & 45 & $-\mathbf{0 , 3 5}$ & $\mathbf{0 , 0 1 7 3}$ \\
\hline MH & 45 & $-0,21$ & 0,1576 \\
\hline PCS & 45 & $-\mathbf{0 , 3 7}$ & $\mathbf{0 , 0 1 1 8}$ \\
\hline MCS & 45 & $-0,25$ & 0,1017 \\
\hline
\end{tabular}

$\mathrm{N}$ - liczba kobiet, R- korelacja, p- istotność; PF - Physical Function (sprawność fizyczna); RP - Role Physical (ograniczenie aktywności z powodu braku zdrowia fizycznego; BP - Bodily Pain (odczuwanie bólu); GH General Health (ogólna percepcja zdrowia); VT - Vitality (witalność); SF - Social Function (funkcja socjalna); $R E$ - Role Emotional (ograniczenie aktywności z powodu problemów emocjonalnych); $M H$ - Mental Health (zdrowie emocjonalne); PCS - Physical Component Summary (podsumowanie komponentów fizycznych); MCS - Mental Component Summary (podsumowanie komponentów psychicznych)

W analizie związku pomiędzy wskaźnikami jakości życia SF-36v2, a zmiennymi BMI, masa podnoszonych ciężarów w czasie pracy, liczby porodów w tym drogami natury i poprzez cięcie cesarskie oraz częstotliwością wizyt $\mathrm{u}$ ginekologa nie wykazano korelacji istotnych statystycznie.

\section{DYSKUSJA}

Spośród wszystkich badanych kobiet $90 \%$ rodziło, z czego 78,8\% rodziło przynajmniej raz siłami natury. Taka dysproporcja pomiędzy liczbą pacjentek, które rodziły drogami natury, a tymi które miały cięcie cesarskie jest zbieżna z wnioskami wynikającymi z przeglądu systematycznego dokonanego przez norweskich badaczy Rørtveit i Hannestad. W tejże pracy wykazali, iż u kobiet które rodziły drogami natury częściej występowało obniżenie narządów rodnych oraz nietrzymanie moczu w porównaniu do tych które miały cięcia cesarskie [6].

Nadwaga i otyłość są czynnikami zwiększającymi ryzyko występowania zaburzeń statyki narządu rodnego [8]. Badania własne zdają się potwierdzać ten fakt, gdyż wśród respondentek, aż 66,7\% miało nadwagę, a u 20\% stwierdzono występowanie otyłości.

W badaniach Rodríguez-Mias i wsp. przeprowadzonych na grupie 1042 kobiet podjęta została próba zidentyfikowania czynników wpływających na występowanie obniżenia narządu rodnego oraz wysiłkowego nietrzymania moczu. Wykazano, iż kobiety z zaburzeniami statyki narządu rodnego częściej miały za sobą porody zabiegowe oraz częściej rodziły dzieci o zwiększonej masie ciała [8]. W badaniach własnych 15\% respondentek miała poród zabiegowy, a 27,5\% urodziła dziecko o masie ciała powyżej 4001 gram.

Jednymi z najczęściej wymienianych przez badane objawów związanych z zaburzeniami statyki narządu rodnego były parcie na mocz (73\%) oraz nietrzymanie moczu $(66,7 \%)$. Powyższe dolegliwości mogą znacząco obniżać jakość życia kobiet, co potwierdzają badania PopłockiejMolińskiej i wsp. [9]. Wykazano w nich, że nietrzymanie moczu obniżało jakość życia respondentek w sferze życia rodzinnego (72\%), zawodowego (49\%) oraz społecznego (40\%).

W badanej grupie kobiet stwierdzono obniżenie jakości życia w każdym z obszarów uwzględnionych w kwestionariuszu SF-36v2. Podobne wyniki w swoim badaniu uzyskał Chan i wsp. W grupie 308 kobiet $\mathrm{z}$ obniżeniem narządu rodnego dokonał on oceny jakości ich życia między innymi przy użyciu formularza SF-36 [10]. Podobnie jak w badaniach własnych jakość życia badanych była niższa od normy założonej przez autorów kwestionariusza.

\section{WNIOSKI}

Średnia jakość życia respondentek była niższa w zakresie wszystkich obszarów kwestionariusza SF-36v2 od przyjętej przez jego autorów normy.

1. Wiek badanych kobiet istotnie wpływał na obniżenie subiektywnej oceny jakości ich życia w obszarach takich jak: aktywność fizyczna, ograniczenie aktywności związanej z brakiem zdrowia fizycznego, odczuwanie bólu, funkcja socjalna, ograniczenie aktywności z powodu problemów emocjonalnych oraz podsumowanie komponenty fizycznej.

2. Nie wykazano istotnego statystycznie związku pomiędzy BMI, masą przedmiotów podnoszonych w trakcie pracy, liczbą porodów oraz częstotliwością wizyt u ginekologa a subiektywną oceną jakości życia respondentek.

3. Najczęściej występującymi objawami związanymi z zaburzeniami statyki narządu rodnego było odczuwanie parcia na mocz, obserwowanie wysuwania się narządu rodnego z pochwy, nietrzymanie moczu oraz zwiększona częstotliwość jego oddawania.

\section{REFERENCES/PIŚMIENNICTWO}

1. Bump RC, Norton PA. Epidemiology and natural history of pelvic floor dysfunction. Obstet Gynecol Clin North Am. 1998;25 (4): 723-746.

2. Persu C, Chapple CR, Cauni V, et al. Pelvic Organ Prolapse Quantification System (POP-Q) - a new era in pelvic prolapse staging. J Med Life. 2011; 4: 75-81.

3. Polskie Towarzystwo Uroginekologiczne: Skala POP-Q obniżenia narządów miednicy mniejszej 2014. Cytowany dn. 13.11.2017. Adres: http://ptug.pl/wp-content/uploads /2014/09/POP-Q_Reference_Ethicon.pdf.

4. Polskie Towarzystwo Uroginekologiczne: Interdyscyplinarne wytyczne Polskiego Towarzystwa Uroginekologiczne odnośnie diagnostyki i leczenie obniżenia narządów miednicy mniejszej. 2014 Cytowany dn. 13.11.2017. Adres: http://ptug.pl/ algorytmy-postepowania/intersdyscyplinarne-wytyczne-polskiego-towarzystwauroginekologicznego-odnosnie-diagnostyki-i-leczenia-obnizenia-narzadowmiednicy-mniejszej.

5. Lewicka M, Sulima M, Pyć, M, i wsp. Ocena ryzyka zaburzeń statyki narządu rodnego wśród kobiet. Medycyna Ogólna i Nauki o Zdrowiu. 2012; 4(18): 398-401.

6. Rørtveit G, Hannestad YS. Association between mode of delivery and pelvic floor dysfunction. Tidsskr Nor Laegeforen. 2014;14; 19 (134): 1848-1852.

7. Lee UJ, Kerkhof MH, van Leijsen SA, Heesakkers JP. Obesity and pelvic organ prolapse. Curr Opin Urol. 2017; 5 (27): 428-434.

8. Rodríguez-Mias NL, Martínez-Franco E, Aguado J et al. Pelvic organ prolapse and stress urinary incontinence, do they share the same risk factors? Eur J Obstet Gynecol Reprod Biol. 2015;190: 52-57.

9. Połocka-Molińska M, Jakóbczak B, Plagens-Rotman K. Wpływ nietrzymania moczu na jakość życia kobiet. Pol Prz Nauk Zdr. 2017;2 (51): 161-167.

10. Chan SS, Cheung RY, Yiu KW et al. Symptoms, quality of life, and factors affecting women's treatment decisions regarding pelvic organ prolapse. Int Urogynecol J. 2012; 8 (23): 1027-1033 
Praca przyjęta do druku/Manuscript received:

16.11.2017

Praca zaakceptowana/Manuscript accepted:

11.01.2018

Tłumaczenie/Translation: Julia Nawrot 